Arch. Dis. Childh., 1965, 40, 80.

\title{
EXTERNAL INJURY CAUSING FOETAL DEFORMITY
}

\author{
BY \\ E. HINDEN \\ From Whipps Cross Hospital, London
}

(RECEIVED FOR PUBLICATION JUNE 16, 1964)

Mechanical injury to the mother's abdomen, causing damage to a foetus in utero, must be an extreme rarity; I can find but one reference. Sheldon (1962) quotes 'Gibb, 1858' (no other details supplied) as follows.

'Accidents and injuries to the mother's abdomen may sometimes damage the foetal brain-this was so in an infant who died at birth and was found to have an old haemorrhage in the right hemisphere which had resulted from a severe blow by a plank of wood on the mother's abdomen.'

This reference is over a century old. Neither Potter (1961) nor Willis (1962) in their exhaustive treatises on foetal pathology mention external trauma as a pathogen. In his long account of prenatal damage, Pliess (1962) says,

'While formerly mechanical influences (nonpenetrating abdominal injuries) as a cause of deformity were considered the more important, nowadays radiation . . . and amniotic puncture. . . .'

and there leaves the subject. He gives but one reference out of a bibliography of 606 items. This reference (Wiedemann, 1955) is as follows.

'Mechanical factors causing damage may occasionally lead to the death and rejection of the foetus, but they have previously been very much exaggerated, to say the least, as causes for prenatal malformations or disease.'

Neither of these last two writers quotes any example. The following case history may therefore be of interest.

\section{Case Report}

Marina X, the fifth child of Greek-Cypriot parents, was born at Forest Gate Hospital on October 12, 1958. The pregnancy and delivery were apparently quite normal, but it was noticed at birth that there was an unusual fresh scar across the bridge of the child's nose, which was depressed as though pushed in. There was speculation as to the cause of this, but no firm diagnosis was made. Mrs. X, who was concerned about the well-being of her other children, did not stay the usual 10 days (she left after 4) so I did not see the baby at my usual neonatal round.

The child grew and developed normally till June 1960. She then suffered from a swelling of her left eye, with fever; this soon got better. In July she sustained her first fit, a major convulsion. The fits persisted, and in October of that year she was admitted to St. Mary's Hospital, Plaistow. Treatment did not control the convulsions, so in December 1960 she was referred to Dr. Sandifer at The Hospital for Sick Children, Great Ormond Street. A radiograph at that time showed 'a midline bone defect on the right of the nose associated with a defective development of the nasal bones' (Fig.), but neurological examination was essentially negative. She was referred to the plastic surgeon for treatment of her nose.

Her condition did not change until July 11, 1961, when she was admitted to The Hospital for Sick Children for the first time because of a prolonged seizure which had started at 9.30 p.m. the previous evening, with a right hemiplegia. Intensive neurological and neurosurgical investigations were carried out, culminating in a craniotomy on August 25. This showed enlargement of the left lateral ventricle of the brain, which did not communicate with the rest of the ventricular system. The surgeon commented that he did not find the expected signs of increased intracranial tension. An opening was made through the septum pellucidum to restore circulation of the cerebrospinal fluid. The child made a good recovery, though the hemiplegia persisted.

There was no major change in her condition thereafter. She was admitted twice subsequently for intercurrent minor infections, and once for probing of her lachrymal ducts. This attempt was not successful, and further operation is under consideration. Her right foot was spastic and her right hand clumsy, but she had no great disability. In September 1963, when she was not yet 5, she was accepted by her local primary school. However, the head teacher soon saw that her physical and mental performances were not normal, thought she was 'spastic', and asked for an ascertainment of her educational needs. Accordingly she was examined at a conference at the West Ham Development Clinic.

At this conference (October 11, 1963) the above history 


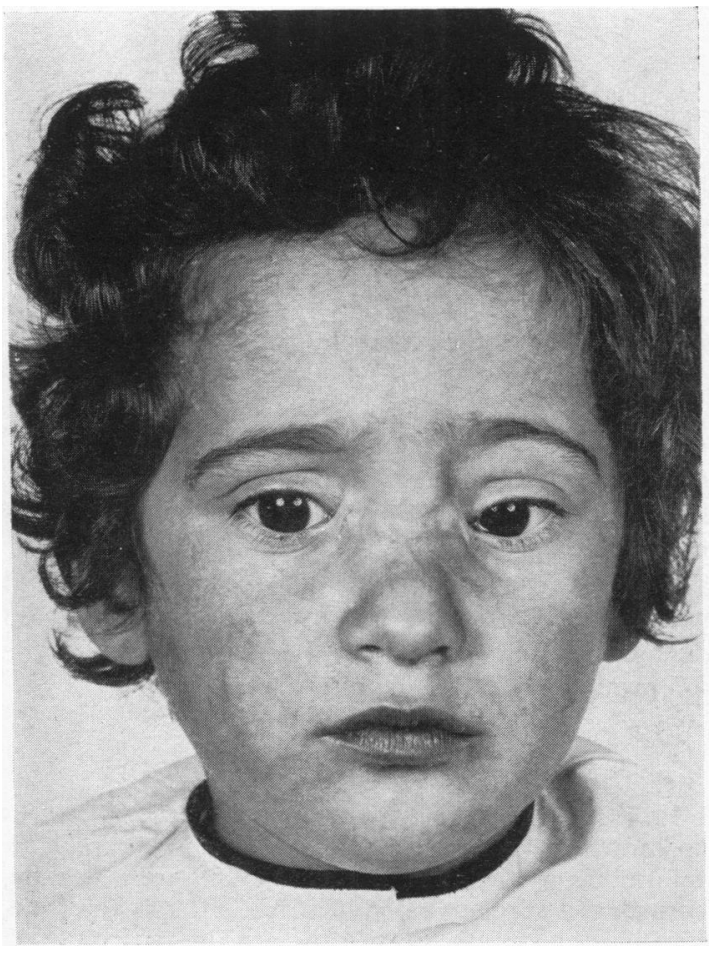

FIG.-Appearance of child.

was presented, together with an I.Q. test (revised StanfordBinet, form L) of $65 \%$. We found a pleasant, somewhat retarded child, with a mild residual hemiplegia. But a vital piece of evidence, hitherto unrevealed, was brought out. Mrs. X's mother-tongue is Greek and her knowledge of English poor, so she does not talk about herself much. However, over the years her health visitor has built up a warm relationship with her. Recently Mrs. X told this lady that when she was 6 months pregnant, she had fallen down some steps into a basement area, striking her abdomen, a little above the pubis, on a metal bootscraper fixed at the foot of the steps. Her abdominal wall was badly bruised ('it was all black and blue') and very sore; at night she found it hard to get to sleep as she could not settle herself in comfort. She also noticed that the foetal movements, which had been vigorous till then, stopped abruptly. She was very upset and frightened by this accident, and deliberately delayed her next antenatal visit till all the bruising had gone: this took four weeks.
By that time the foetus was moving again; she hoped all was well and did not report the occurrence.

When she saw the baby after birth, she at once connected the damaged nose with the blow on her abdomen, and tried to explain this to her attendants. But her English was quite inadequate; she saw she was not being understood, and gave up the attempt.

\section{Comment}

Everyone who saw the baby at birth wondered at the scar; it did not conform with the usual developmental abnormalities; it looked like an injury. While it seems most likely that the foetus did sustain an intrauterine injury, crushing the bridge of her nose and causing gross damage to her brain, it is not possible to assert this dogmatically. Congenital deformity may take bizarre forms and could be responsible. This is the view of Prof. R. A. Willis (personal communication). Dr. Edith Potter (personal communication) also thinks that it is not proven that trauma caused the child's condition. However, bearing in mind the injury during pregnancy and its effect upon the foetus at the time, the obvious scar on the infant's face at birth, and the unusual damage to the nasal bones and the nasolachrymal duct, it seems barely credible to assume that all this is simple coincidence with non-traumatic congenital malformation.

It remains to consider the nature of the neurological lesion. This may have been a haemorrhage blocking the foramen of Monro; but Dr. K. M. Laurence (personal communication) suggests that it may have been a porencephalic cyst, distorting the ventricular system.

I would like to thank Mr. D. N. Matthews, Mr. K. Till, and Dr. P. H. Sandifer, of the Children's Hospital, for their helpful comments and for permission to quote from their findings. I also gratefully acknowledge the help given by Dr. H. R. Dennison, M.O.H. of West Ham, and his team of health visitors.

\section{REFERENCES}

Pliess, G. (1962). Praenatale Schäden. Ergebn. inn. Med. Kinderheilk., 17, 264-384 (on page 362).

Potter, E. L. (1961). Pathology of the Fetus and the Infant, 2nd ed. Year Book Medical Publishers, Chicago.

Sheldon, W. (1962). Diseases of Infancy and Childhood, 8th ed., p. 477. Churchill, London.

Wiedemann, H. R. (1955). Schädigungen der Frucht in der Schwangerschaft. Med. Mschr., 9, 141.

Willis, R. A. (1962). The Borderland of Embryology and Pathology, 2nd ed. Butterworth, London. 